\title{
The Re-Appearance of God: Ana-Liturgy
}

\author{
\#iwalkalong special \#thepassion I walk along for my grandson [...] \\ who fights for his life in the IC of UMCG Groningen \\ TWEeT, 17 April 2014
}

\begin{abstract}
After the fireworks explosion in 2000 that destroyed the residential area Roombeek, here in Enschede, there was a huge sense of unity. Today, we have come to The Passion on this large square to experience that same sense of unity.

TWO FEMAle INHABitants OF ENSChede, April 2, 2015

(interview on H.J. van Heek Square, MK)
\end{abstract}

Walking the procession can be a very spiritual experience, I think. Maybe people can leave suffering behind and make a new start. [...] The procession is a sort of spring cleaning.

BRIDGET MAASLAND, procession news reporter at The Passion, 20 March $2015^{1}$

Secularisation in the Netherlands has been qualified in the preceding chapters as the 'receding of Christendom.2 ${ }^{2}$ The two biggest churches (the Protestant

1 During the show, there is live coverage of the procession by a famous TV personality in the role of news reporter. In 2015, dancer, show host, model and animal rights activist Bridget Maasland played this role. The quotation (translation $\mathrm{MK}$ ) is taken from a promotional clip for The Passion 2015. See "Processie is soort grote schoonmaak", EO Visie, March 20, 2015, video. https://visie.eo.nl/2015/o3/processie-is-soort-grote-schoonmaak/. Last accessed May 10, 2020.

2 This chapter is a revision of an article with material presented in two different papers, that was previously published as Mirella Klomp and Danie Veldsman, "After God, But Behind the 
Church in the Netherlands and the Roman-Catholic church) continue to see decreasing membership, the Roman-Catholic church struggles with diminishing vitality, and churches face increasing marginalisation in society. ${ }^{3}$ Christian belief, experiences and practices show a trend of waning theism. The practices of Christian faith have receded in the past five decades, but the recession has intensified in the past ten years, according to the 2016 research report GIN. The report also revealed a strong reduction in a transcendent worldview $(6 \circ \%>$ $42 \%)$ and an increase in agnostic and atheist worldviews (40\% > 58\%) among the Dutch over the past decade. ${ }^{4}$

In the Prologue to this book, I made some critical remarks about methodological approaches which measure religion by the extent to which people subscribe to (a set of) religious beliefs, and the theory of religion that underlies such approaches. It is nevertheless interesting to observe recent developments in the degree to which people subscribe to what the authors of GIN call the 'basic beliefs' of Christianity. ${ }^{5}$ In 2016, fewer people subscribed to the belief that Christ is the son of God or was sent by God (40\% > 28\%) than in 2006; fewer people considered the Bible to be (fully or partly) the Word of God $(51 \%>35 \%)$ while many more people indicated that they did not know $(7 \%>$ $22 \%)$; fewer people believed in some sort of afterlife $(40 \%>23 \%)$, while more people had doubts $(31 \%>37 \%)$ and many more had come not to believe in an afterlife in any form $(29 \%>40 \%) .{ }^{6}$ It seems that people are becoming less able to relate to the beliefs or dogmas that of Christian traditions over the course of time. They are beyond 'traditional' images and ideas of God, and, in the wake of this, let go of God. ${ }^{7}$

Cross. The Procession as a Way to Re-encounter God in a Culture Beyond Classical Liturgy", Studia Liturgica. An International Ecumenical Review for Liturgical Research and Renewal 47, no. 1 (2017), 15-29. In part this chapter is also based on Mirella Klomp, “The Passion' met God als optie", Kerk en Theologie 66, no. 2 (2015), 134-140. I want to express my gratitude to my colleague and friend Danie Veldsman with whom I extensively discussed the work of Kearney in relation to the case of The Passion, and who provided valuable feedback on my paper presentations and the text.

3 Bernts and Berghuijs, God in Nederland 1966-2015, 30-31.

4 Bernts and Berghuijs, God in Nederland 1966-2015, 64-65. The report used the following classification: theists are people who believe in a God who is personally involved in the life of every human being, somethingists are those who believe in a higher power that controls peoples' lives, agnostics are those who do not know whether or not there is a God and/or higher power, and atheists are people who do not believe in a God or higher power.

5 Bernts and Berghuijs, God in Nederland 1966-2015, 66.

6 Bernts and Berghuijs, God in Nederland 1966-2015, 64-72.

7 The word 'traditional' is not unproblematic as, in the context of religion, it often has connotations of old-fashioned and orthodox. However, I do not use it in a pejorative sense, 
In the Prologue, I identified the paradox that a contemporary multi-media event, based on the religious narrative of the suffering and death of Jesus Christ, has become so popular in a 'secularised' country. One element that has been part of The Passion from the very beginning and which has expanded over the course of subsequent editions demonstrates this paradox in a poignant manner: the procession with a large, neon lit white cross. In a society 'after God', over a hundred thousand people gather 'behind the cross'. The research report GIN makes clear that people have not made a large-scale return to 'traditional' Christian belief. But although they may not actively seek God, the popularity of The Passion raises the suspicion that there is at least some kind of openness towards elements of Christian heritage or Christian repertoire. This raises the question of whether it is possible that people return to God after God, in a way different from the past. Can we speak about God after God, and if so, how?

In this chapter, I use the qualitative research data that I collected on the procession of The Passion to investigate how, in the various forms of the procession ritual, God may come up and may be encountered. As a theologian, I identify the key issue as the sacramental quality of late-modern Christian repertoire, more specifically, the encounter with God through, with, and in rituals. The experience of many people in 21st century Western European societies, that Christianity has become unbelievable, calls for the further development of 'theology after the death of God'. This chapter aims to contribute to this development by theologically exploring how God could be encountered in the procession practices of The Passion.

Those taking part in the procession - even those whose stories I tell in this chapter - may well not endorse my theological interpretation, or may even emphatically object to it, largely because they themselves do not explicitly interpret the procession as a sacred or religious practice. This directly touches on what Tone Stangeland Kaufland has termed a practical theological conundrum: the relationship between normative and descriptive dimensions in practical theological work. Giving an overview of various possible relationships, Kaufland has presented a grid of practical theological positions. ${ }^{8}$ I position my effort to understand the return of God after God in this chapter as, what she calls, a practice-oriented approach, where no voice is given primacy

but literally: images of God have taken shape as Christian tradition has developed over the course of time.

8 Tone Stangeland Kaufman, "From the outside, within, or in between?" in Conundrums in Practical Theology, Theology in Practice 2, eds. Joyce Ann Mercer and Bonnie MillerMcLemore (Leiden/Boston: Brill, 2016), 134-162, esp. 139. 
in advance: "Here human experience and the practice encountered in the empirical field studied are granted the position of possibly revising or reshaping the received tradition. (...) Neither normative dimensions nor "the theological" can be nicely located or placed in any one of the steps of a practicetheology-practice model (...). Rather, these dimensions are embedded in the entire practical theological undertaking or the practice of practical theology". ${ }^{9}$ Empirical data on the procession shows that participants have many different interpretations of the procession activity, and some of these interpretations are explicitly informed by 'traditional' Christian dogmas. ${ }^{10}$ Yet, these do not work for those in the procession who are 'beyond God' (as the research report GIN showed). This calls for new theological explorations of how, in these practices, God may be encountered. The warrant for this undertaking lies in people's openness toward this late-modern procession, which is expressed by their participation in it. The investigation of the possibility for encountering God is inherent to the radical theology I will turn to in the exploration of new quests for God; new quests demand new language, new images, new concepts that open up spaces for the return of the divine.

I described the case of The Passion in detail in Chapter 1 but will, in this chapter, further elaborate on the three processional forms which The Passion adopts and the Dutch context in which this procession practice takes place. After this, I shall explain the concept of 'anatheism' as developed by Richard Kearney and elaborate why his theory seems promising for an exploration of new quests of God in late modern society. Leaning on Kearney and the possibility of a sacramental encounter with God in this contemporary procession, I will offer a theological interpretation of the ritual.

\section{The Procession}

\section{The Procession in The Passion}

The word 'procession' (from the Latin procedere: to move, to proceed) as I use it here refers to "a communal ritualised act, a social action that can - mainly but not exclusively - be identified as religious".11 This ritualised act in The Passion takes on three distinct but related forms: a physical procession with a cross

$9 \quad$ Kaufland, "From the outside", 143.

10 E.g. Motivations from online processions 2014 and 2015.

11 Albert Gerhards, "Prozession II" in Theologische Realenzyklopädie, 27, ed. Horst Balz et al. (Berlin: De Gruyter, 1997), 593-597, 593 [hereafter cited as TRE]. The translation from the German is mine. 
through the city, a virtual procession behind the cross enabled by a secondscreen application, and a virtual Twitter-procession.

Since the first edition of The Passion in 2011, every year some 1,00o people have physically followed a large neon-lit white cross that is carried through the streets by sixteen so-called "cross bearers". ${ }^{12}$ Each year, the procession heads to the square in order to arrive at the main stage at the point in the narrative where Jesus, after his condemnation, is taken away by soldiers. During the live performance of the show in the city square, where a narrator on stage hosts the performance, cameras switches over occasionally to the procession. At these moments, a TV personality in the role of a journalist interviews several participants in the procession (from various religious and non-religious backgrounds) who openly share with millions of viewers their personal motives for following the cross.

By 2014, this physical procession had become so popular that online registration for participation, which opened six months before the event, was fully booked in just a couple of hours. The organizers, therefore, initiated an additional virtual procession by launching a 'second-screen application', which enabled people to follow the procession online and to share their personal motivation for doing so. ${ }^{13}$ This virtual procession drew so many followers that subsequent iterations of The Passion all had this second-screen application (2015 showed a five-fold increase in participants, see the figures below). During the broadcast of The Passion, people were encouraged to join the virtual procession as the text live.thepassion.nl appeared on screen. Upon visiting the website, they would see a pop-up screen with an "I walk along" button, along with an optional textbox in which people could write their motivation for doing so. ${ }^{14}$ Once enrolled in this virtual procession, participants could see the cross and cross-bearers in front of them, and could follow the procession through the streets of the city by scrolling with their mouse or swiping the

12 The organisation set the limit to 1,0oo participants in order to be able to ensure their safety. Fieldnotes 23 March 2014.

13 Definition of 'second screen': "a mobile device used while watching television, especially to access supplementary content or applications". It is used to enhance the TV viewing experience and often generates online conversations around the content. "Second screen". Oxford Dictionary. http://www.oxforddictionaries.com/definition/english/ second-screen. Last accessed May 10, 2020.

14 Many of these were a 'confessional' type of motivation, shared by Christians bearing witness of their faith. Other types of motivation, however, (e.g. humorous ones, cf. Chapter 5 , or motivations that expressed appreciation of the online procession or the impressiveness of the show) also occurred. 


\begin{tabular}{lcc}
$\begin{array}{l}\text { Year/No. } \\
\text { of people }\end{array}$ & $\begin{array}{c}\text { Virtual participants } \\
\text { (rounded figure) }\end{array}$ & $\begin{array}{c}\text { Motives shared } \\
\text { (rounded figure) }\end{array}$ \\
\hline 2014 & 25,000 & 10,000 \\
2015 & 135,000 & 19,000 \\
2016 & 145,000 & unknown \\
2017 & 111,000 & 15,000 \\
2018 & 86,000 & 32,500 \\
2019 & 14,500 & 2,500 (in chat messages), \\
& & 322 (uploaded videos) \\
\hline
\end{tabular}

FIGURE 6 Overview of round numbers of participants in the virtual procession on the second screen

Source: two emails from Cornelis Vlot, market and communication advisor at broadcasting company EO, received on July 26, 2018 and September 23, 2019, and one email from Maartje Nitrauw, "project manager digital" at EO, on September 23,2019 . Vlot in his last email added a disclaimer regarding the dropped number of the 2019 edition by pointing out that in that year a new format was used "which was more of a barrier for those walking along”. According to Nitrauw, people could "choose to upload a video, or type along in the chat. The reason why we chose for video-uploads has to do with the theme \#youarenotalone. We tried to unpack that theme by posting stories online, also stories of 'normal people."' (So not only interviews and videos with the performers, but also interviews on this topic with those carrying the cross in the procession or other people with extraordinary stories).

touchscreen of their devices. Each participant could virtually walk the procession at their own pace in the direction of the main square..$^{15}$

In addition to the physical and virtual procession, people could also join the online Twitter-procession by using the hashtag \#ikloopmee (\#iwalkalong), an initiative launched and promoted by the broadcasting companies. This created another form of virtual procession, which the creators intended to relate this to the second-screen application so that people could not only share their motivations for following the cross by using the open textbox, but also by sharing them on Twitter. However, in reality, the hashtag was also used more independently, as a way of interacting with The Passion in general. This created a 'hashtag community' of participants, in which people had an 'ambient' affiliation to the procession around which they interacted and in which they did

15 Participants actually followed the procession-rehearsal that was recorded on the evening before the event, which is why they could reach the main stage before the procession did so in real time. 
not necessarily interact directly in order to align around a common practice or symbol. ${ }^{16}$

\section{Historical Background and Cultural Context}

As previously suggested, Christian repertoire in late-modern culture is influenced by broader developments and trends in that culture. The procession in The Passion offered offline and online levels of engagement, and has taken on features of multimediality, virtuality, interactivity and connectivity (see Chapter 5 ). The form may be rather new, but processions have a long history, with antecedents in the practices of ancient Israel, and throughout the history of Christian worship in the East and West, to this day. ${ }^{17}$ Processional rites occur either indoors as part of the liturgy, e.g. entrance processions, gospel and communion processions, processions with gifts; within elements of worship that often have a particular purpose, or outdoors, in which case the meaning often predominantly lies in the act of 'being on the move' itself, as well as in the act of self-presentation or putting oneself out there. ${ }^{18}$ Movement, spectatorship and play are characteristics of the latter type. ${ }^{19}$ The procession with the cross that is part of The Passion obviously fully belongs to the outdoor category (as the online shapes are also linked to the offline, physical forms in the open air) with its corresponding features. It stands in the tradition of processions linked to a Christian feast, in this case, the paschal triduum. Over the course of history, several processions during Holy Week have developed, both strict liturgical processions and others with strong links to popular culture (the medieval passion play has its origins in the latter).

In the context of Dutch culture, processions were, for a long time, a controversial phenomenon. Ever since the Reformation got a foothold in what is

16 Michele Zappavigna, "CoffeeTweets. Bonding around the bean on Twitter", in The Language of Social Media. Identity and Community on the Internet, eds. Philip Seargeant and Caroline Tagg (Basingstoke/New York: Palgrave Macmillan, 2014), 139-16o, here 141-142.

17 For historical overviews and extensive lists of bibliographic references see Jan Christian Gertz, "Prozession I", in TRE, 27, 591-593, and Gerhards, "Prozession II", 593-597. Regarding the relation between indoor and outdoor liturgy, the following are particularly relevant: Paul Post, "Ritual Landscape. On Outdoor Liturgy. Processional Parks, Papal Visits, and Popular Rites Associated with Sudden Death", in The Modern Pilgrim. Multidisciplinary Explorations of Christian Pilgrimage, Liturgia Condenda 8, eds. Paul Post et al. (Leuven: Peeters Publishers, 1998), 281-320.

18 Processions of the blessed sacraments, as well as the stational liturgy, which grew out of the early Christian practice of visiting the tombs of the martyrs and celebrating the Eucharist at those sites, are examples of this type. See Gerhards, "Prozession II", 595.

19 Gerhards, "Prozession II", 595. 
now called The Netherlands, public expression of Roman-Catholic faith within the Republic of the Seven United Netherlands (1561-1795) was prohibited. ${ }^{20}$ Freedom of religion was legally established in 1795 , however, processions were again officially banned by Dutch law in 1848 because the revival of processions and communal pilgrimages had stirred up too much turmoil in the predominantly Protestant country. This law prohibited processions in those parts of the country where they had not been a common phenomenon prior to 1848 . This effectively meant that, north of the rivers Rhine, Meuse and Walloon, processions were disallowed, unless they had always been practiced. The river area served as a natural border between the predominantly-protestant northern part and roman-catholic southern part of the country, occupying $2 / 3$ and $1 / 3$ of the land area respectively. ${ }^{21}$ The ban on processions was eventually dispensed with in 1983, however for a long period, procession in the Netherlands has been a phenomenon that was tolerated but not practiced by the majority of the Dutch inhabitants.

In the 1990s, the abolition of the ban enabled a new procession ritual to arise and develop within Dutch culture: the (compassionate or) silent procession can be described as a kind of disaster ritual. ${ }^{22}$ Today, such processions occur after disasters, after fatalities arising from what is termed "senseless violence" (e.g. street violence), after the sudden death of a prominent persons, in the context of national remembrance of the dead of World War II, and within all sorts of memorial and protest rituals. ${ }^{23}$ Whilst liturgical processions today are rather absent, silent processions like these have become a prominent form of public ritual in the Netherlands, although in Dutch the word procession is seldom used for these practices, and they are referred to, instead, as 'silent marches' ('stille tochten').

Paul Post, in his exploration of outdoor ritual, has typified rituals similar to the procession in The Passion as "folklorised liturgy". Acknowledging that

20 A detailed study of Dutch processional culture, on which this paragraph relies, can be found in Peter Jan Margry, Teedere Quaesties: religieuze rituelen in conflict. Confrontaties tussen katholieken en protestanten rond de processiecultuur in 19e-eeuws Nederland (PhD thesis, University of Amsterdam) (Hilversum: Verloren, 2000).

21 The famous Saint John Procession in Laren, that probably dates back to the 15th century and is still held every year, is an example of the latter. See "Laren, H. Jan (Johannes) de Doper", Meertens Instituut, http://www.meertens.knaw.nl/bedevaart/bol/plaats/422. Last accessed May 10, 2020.

22 For an overview of the development of this kind of procession, see Paul Post, "Case studies I: Dutch cases and themes" in Disaster ritual. Explorations of an emerging ritual repertoire, Liturgia Condenda 15, eds. Paul Post et al. (Leuven: Peeters Publishers, 2003), 156186.

23 Post, “Case studies I", 166-172. 
the term is somewhat problematic, Post has rightly pointed to "a fundamental change in the context of ritual and the way it is experienced". ${ }^{24} \mathrm{He}$ has signalled a change in liturgical shape, context, and meaning: ritual moves into the public realm, where it takes the form of a performance for an audience and becomes a spectacle with all the associated rehearsals, scripts, and sponsors. Although Gerhards has described the activity of spectating as part and parcel of a procession, the procession of The Passion affirms that professionalisation and commercialisation are irrefutably part of the tendency that Post describes. The processional practices in The Passion are clear examples of such change, and stand in the broader context of the transfer and transformation of religion as described in Chapter 2. Many people in the Netherlands are relatively unfamiliar with liturgical and/or religious processions; they are likely to be somewhat more familiar with compassionate/silent processions, and these may well form part of their framework when making sense of the procession of The Passion (see Chapter 4). Due to the increase in media attention that The Passion has received over the years, the word "procession" is now used in the public sphere (e.g. in newspapers and TV and radio talk shows) as if it has always been a perfectly normal and customary phenomenon. Yet the historical background of procession rituals and the current religious landscape in the Netherlands make the practice and appropriation of the procession in The Passion a complex and diffuse rather than unequivocal phenomenon.

\section{A Return to God after God: Kearney's 'Anatheism'}

In light of the new quests for God which I read into practices that take place in late-modern network societies, I now turn to explore how an encounter between God and participants may be able to take place in the complexity of this multi-layered procession practice. This exploration may create a susceptibility to the possibility of encounters with God in times when Christian belief is experienced as unbelievable. The philosophical-theological reflection of Richard Kearney on the return to God after the loss of God leads us to a creative hermeneutic through his proposal of a sacramental imagination that entails the sacramental return to the holiness of the everyday. ${ }^{25}$

\footnotetext{
24 Post, "Ritual Landscape", 294-295.

25 The procession with the cross is not simply 'the everyday' though: it is actually a combination of a set-apart object (i.e. the cross) and the everyday of work, watching tv and posting Twitter-messages, as the elaboration of empirical examples below will show. This combination enables the sacred/divine to enter practices of everyday life.
} 
In a late modern Western context, Kearney claims that the question of God is returning with a new sense of urgency. He believes the question to be "an increasingly pressing inquiry for our 'postmodern' age where the adversarial dogmas of secularism and absolutism threaten the option of considered dialogue". ${ }^{26}$ In his book Anatheism, he poses the deeply penetrating question of how we can speak of God after having left God behind: "What comes after God? What follows in the wake of our letting go of God? What emerges out of the night of not-knowing, that moment of abandoning and abandonment? Especially for those who - after ridding themselves of 'God' - still seek God?"27 Kearney's answer to the question 'what comes after God' finds expression in his formulation of a pathway between contemporary dogmatic theism and militant atheism (and, I would argue, agnosticism) - a way that offers a hermeneutical narrative approach with its interpretative focus on 'otherness' and the welcoming of the S/stranger. Anatheism is "an invitation to revisit what might be termed a primary scene of religion: the encounter with a radical Stranger who we choose, or don't choose, to call God". ${ }^{28}$ It is a third way between the polar opposites of certainty "that have maimed so many minds and souls in our history" through which Kearney explores the exciting interpretative possibilities of a "return" to God and a re-imagining of God after the death of God. ${ }^{29}$ Crucial to this third way is the existence within it of moments both of atheism and of theism: it is a return to God after the disappearance of God (ana-theos), a way between naïve faith and the hermeneutic of suspicion. Ana-theism is "another word for another way of seeking and sounding the things we consider sacred but can never fully fathom or prove". ${ }^{30}$ For Kearney, anatheism is not a state, but rather a wager of faith beyond faith that occurs again and again; a wager that "marks a reopening of that space where we are free to choose between faith or nonfaith"; ${ }^{31}$ a moment of creative "not-knowing" that signifies a break with former sureties and invites people to forge new meanings; a movement that refuses all absolute talk about the absolute. Such moments by no means occur only to intellectuals: the anatheist moment can come upon anyone who experiences anxiety, doubt, or disorientation in life. These instants are "experienced

\footnotetext{
26 Kearney, Anatheism, xiii.

27 Kearney, Anatheism, 3.

28 Kearney, Anatheism, 7.

29 Kearney, Anatheism, 2.

30 Kearney, Anatheism, 3.

31 Kearney, Anatheism, 7.
} 
in our bones - moods, affects, senses, emotions - before they are theoretically interrogated by our minds. And they are (...) as familiar to believers as to non-believers". 32

An important element of Kearney's theory is the sacramental imagination. For him, this entails what he terms a sacramental return, a retrieval of the extraordinary in the ordinary: "It marks an opening toward a God whose descent into flesh depends on our response to the sacred summons of the moment". ${ }^{33}$ In this sense, anatheism is a form of post-theism that allows us to revisit the sacred in the midst of the secular. A revisitation that confirms specific rejections: a rejection of the Omni-God of celestial might; a rejection of the idea that God orchestrates good and evil alike. If anything is dead, it is the traditional idea of God, that is, a God as Deus ex machina in times of neediness. Also, if anything is dead, it is the modern individualist conception of private salvation. The sacramental return "is the possibility of a God after God (ana-theos) that signals the return of the sacred after its setting aside (ana-thema)". ${ }^{34}$

Kearney's theory is fruitful for both the interpretation of the procession ritual in The Passion and wider interpretation of contemporary (Christian-rooted) ritual repertoire. By analogy with his 'return to God after God', the procession in The Passion may be described as 'a return to liturgy after the liturgy'. In any one of the three shapes, the procession in The Passion can be understood as ana-liturgy. To many inhabitants of the Netherlands, a procession with a cross is, in many ways, like a complete stranger. In a society where, in the 2oth century, Christianity was increasingly met with hostility and where it has now become mostly irrelevant to many people, this procession - still unequivocally related to the cross of Jesus Christ - is somehow being embraced (I will elaborate how in three sub-cases below). Wherever the procession goes, people participate in the wager. The result of this anatheistic wager is by no means fixed or final: people either choose to follow the cross or they do not. If and when they actually follow the cross, they receive the stranger as a guest. It is their response to the sacred summons of the moment. They allow the stranger to come closer. It may bring them something new. This does not, of course, mean that all those engaging in the offline and online procession consciously experience anatheistic moments, or that they are aware of being in 'a middle section' where they can either choose belief or disbelief. In Anatheism, Kearney approaches the anatheistic wager as a rather individual and rational affair, yet I

32 Kearney, Anatheism, 5.

33 Kearney, Anatheism, 86-87.

34 Kearney, Anatheism, 86. 
propose that there is more space for communality and unintentionality than Kearney admits. ${ }^{35}$

The communality of the anatheistic wager returns in the fact that the mass event is a collective practice, but also in the interpretation of the practice, which is an act performed by participants and scholars alike. Kearney's anatheistic proposal is fundamentally a project of theo-poiesis (Greek, in Latin: theo-poetics): of "God made present in and through making". ${ }^{36}$ It clears spaces for the return of the divine, and this requires humans to become co-creators in the process. "We must return to a God who returns to us. We must aid and even provoke the reappearance of the sacred by rejoining the endless art of creation. Indeed, by opening ourselves to the possibility that we can make with, in, and through God, we may find that the impossible has been made possible - that God makes with, in, and through us". ${ }^{37}$ Practical theology demands that the 'we' in this quotation is taken to refer to participants in the ritual and practical theologians together. On the basis of the research report GIN, I have concluded that many people in the Netherlands no longer actively seek God, and that The Passion does not really arouse curiosity about Christian faith. Yet, the popularity of the procession (measured by the number of participants) demonstrates a certain openness towards the cross. There is a normative dimension to this openness - the normativity of participants who participate in the ritual as the result of an evaluative decision ('in the wager', this is elaborated in more detail below). This allows for theologians to take this one step further and explore the openness as a space where the divine may return (the sacramental encounter being a normative perspective too) an exploration that takes the form of words, of theory, but is performed in line with the openness of participants. Participants in the ritual, together with practical theologians, thus engage in theo-poetics: "a process of creating and recreating the divine in the wake of the death of God".38

Although Kearney writes that the wager of discernment may occur at the most basic affective and pre-conceptual levels, the wager of response is not, in his view, irrational: “... every seeing is a seeing as, a reading of the Stranger as

35 Strikingly, despite many opportunities in his philosophy that allow for an anatheistic interpretation of ritual, Kearney in Anatheism mainly focused on texts, sacred stories/narratives, poetry and art. The volume edited by Kearney and Clemente, The Art of Anatheism, that was published in 2018, has a wider scope as it presents other kinds of art practices as anatheistic projects as well.

$36 \quad$ Kearney and Clemente, The Art of Anatheism, viii.

37 Kearney and Clemente, The Art of Anatheism, viii.

$3^{8} \quad$ Kearney and Clemente, The Art of Anatheism, viii-ix. 
this or that other, as love or hate, life or death". ${ }^{39}$ The difficulty here is that, in the end, what comes out of the wager for Kearney often seems closely bound up with a verbal act (cf. "the radical Stranger who we choose, or don't choose, to call God"40). His theory therefore runs the risk of becoming limited to the mind, to convictions, thoughts and ideas. I want to emphasize, instead, that a return to God, particularly within a 21st century culture of emotion and experience, may also occur in the acting itself. Even without words, it is possible to welcome the stranger in the ritual - a ritual that is often performed together with other people. No matter how small the act of clicking a virtual button, irrespective of the ambivalence that some participants, who physically follow the cross through the streets of the city feel, regardless of the impermanence of their engagement, they act and, by acting, welcome the stranger at their gates. Experiencing rituals as unfolders of meaning within the inviting realms of open spaces does not necessarily entail intellectual consent or theoretical interrogation as a prerequisite. The procession of The Passion is like a stranger walking up to people in Dutch society today. They turn on the television and the web link to the virtual procession pops up - the stranger is knocking on their doors, and they simply engage or refrain from engaging in this collective ritual procession.

\section{Encountering God in Ana-Liturgy}

If, in the ana-liturgical ritual, people indeed encounter the radical stranger whom they may or may not call God - then how might this work? I will discuss this question through three examples from participants in the procession in 2014 and 2015. From a large set of empirical data collected between 2011 and 2016, I chose these examples because they show the diverse ways in which the procession can be seen as ana-liturgy in which God may be found afresh.

\section{Empowering Powerlessness: Firemen in the Physical Procession}

In 2015, The Passion in Enschede took place shortly before the fifteenth anniversary of a catastrophic fireworks explosion that had destroyed the residential area Roombeek. In 2000, the storehouse of a fireworks trader went up in flames, twenty-three people (four of whom were firemen) died, around

39 Kearney, Anatheism, 44-45, italics his.

40 Kearney, Anatheism, 7. Kearney here seems to be "in the word" rather than "in the flesh" (to refer to the title of his chapter on sacramentality and the body), which seems to emphasise his initial verbal focus. 
$95^{\circ}$ persons were injured and 200 houses were destroyed. The calamity had a great impact on the community. Six days after the accident, a silent procession was organised, in which over 100,000 people participated. ${ }^{41}$ In The Passion in 2015 , the physical procession with the cross started in the heart of the (rebuilt) residential area of Roombeek and from there headed to the city centre. Upon the request of the local fire-brigade, several firemen were cross-bearers in this procession. In a preparatory interview between the organising team and the firemen, they appeared to have concrete motivations for joining the procession. One man made clear that by walking in the procession he meant to honour his colleagues who had died in the accident.

At that time, I had only just begun to work at the fire brigade and was only on the side-lines (...), but after fifteen years I notice that the accident still greatly influences the work of the fire department. ${ }^{42}$

Another fireman in that pre-interview had been involved more directly:

I was on one of the first five fire trucks that rode out and ended up in the middle of the explosions. I lost consciousness on site, but I continued working in the days after the fire. It was much later that I got health problems. I had serious whiplash and was medically disqualified from working for $6 \circ \%$ of my regular working hours. The catastrophe literally and figuratively left its scars. ${ }^{43}$

These men do not speak about God, they are living their lives in their regular social circles, and from out of that context, on a particular evening, they join in with a ritual with a cross: they act. Their situation does not necessarily change their acting or the meaning they ascribe to the procession or the cross, but it certainly changes $m y$ view of God. They poignantly take an obviously religious narrative (the passion) and symbol (the cross) in order to readdress their suffering to those present both on the communal level of the fire department, and on their own individual scale, both for others in the Roombeek area and for the broader community of Enschede's inhabitants. In so doing, these firemen unintentionally make visible the way in which the image of God was changed by the suffering of Christ when he carried the cross to which he

41 Source: EnToen.Nu. Canon van Nederland. "Canon van Enschede". https://www.entoen .nu/nl/overijssel/twente/enschede/vuurwerkramp-. Last accessed May 10, 2020.

42 Source: Line-up of The Passion 2015.

43 Source: Line-up of The Passion 2015. 


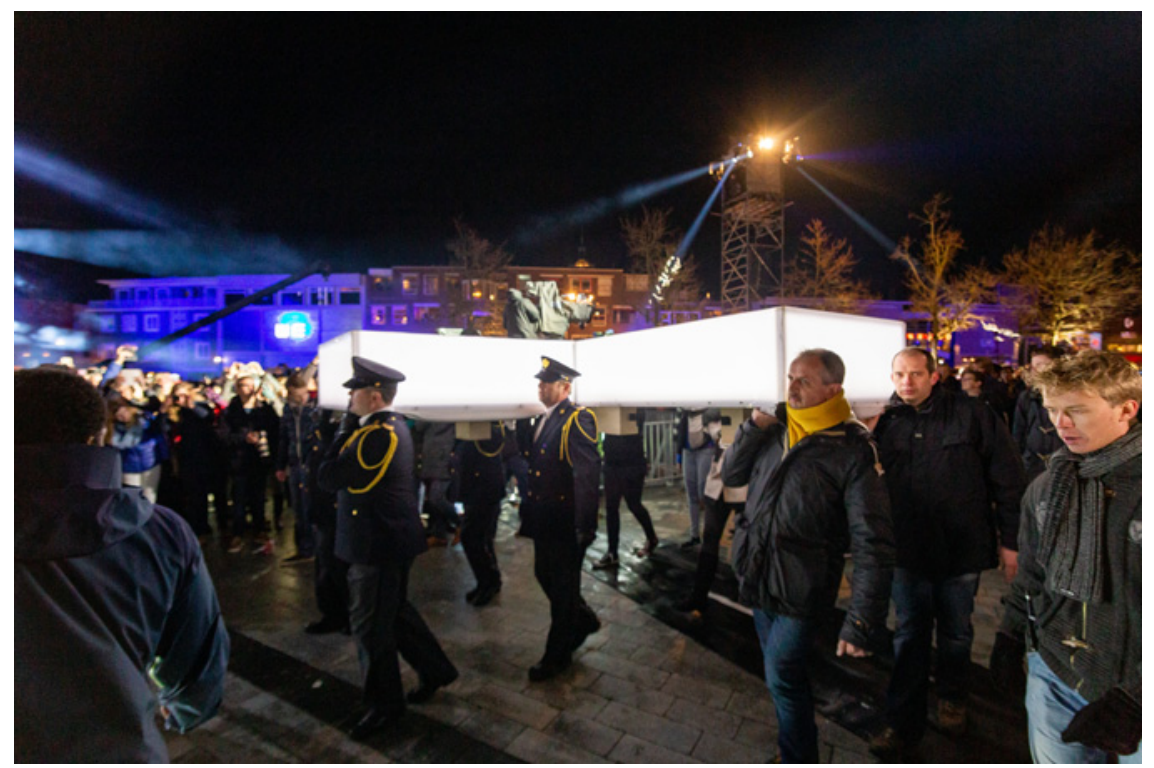

FIGURE 7 Firemen carrying the neon-lit cross

PHOTO: ROGIER VAN DEN BERG. (C) RTV OOST

would later be nailed and on which he would die. We can interpret their ritual acting as an encounter with the divine. Their acting raises the idea that, in the passion, God may have changed more radically than theologians have long thought: in the extraordinary moment and place and setting where they pick up the cross, I want to say that God can become present. The firemen may have participated in the silent march in 200o, but this time, during the procession, they are carrying a cross, which has very explicit theological connotations. As they walk with the cross, it becomes clear to us how the suffering Christ may walk with them.

Participation in the ritual creates a space where an encounter between the firemen, the commemorating community, and the weak God can happen. The anatheist moment involves, in the words of Kearney, "a hope in spite of hopelessness that the estranged God may return in its empowering powerlessness", a sentiment echoing Bonhoeffer's earlier formulations. ${ }^{44}$ When commemorating in situ, the hope that comes with rebuilt houses, streets, parks, and playgrounds stands next to the hopeless, utter darkness of the catastrophe and its still-visible scars. In this ritual, the God of the past, who is the God still to come,

44 Kearney, Anatheism, 68. 
may descend. In an ordinary residential area, in a procession with a Plexiglas cross, the divine may enter with weakness and vulnerability to meet his suffering people. In this perspective, the procession in the Roombeek area is a sacramental return of the holiness of the everyday: a space where the extraordinary may be retrieved in the ordinary. In this procession, the cross-bearers return to "a liturgy after the liturgy", in which the possibility is opened up that they meet a Stranger who suffers and dies, who empowers with powerlessness, who is weak and vulnerable. One whom they may or may not call God.

\section{Letting Go of God:A Lamenting Mother on the Second Screen}

I want to learn to understand why my son was taken away this early, in the prime of his life. I think we need him more than god or Jesus [does], if they do at all exist. My faith had not been very strong, but it was completely taken away from me after the death of my 19-year-old son. How to explain this 'in the love of Jesus'? To my mind that is not possible. Still, I walk along, virtually, maybe I will get an answer some time. But frankly I expect nothing. ${ }^{45}$

On 17 April 2014, a mother entered this text in the text box on the secondscreen application, in order to explain her motivation for joining the virtual procession in Groningen. The text strongly reflects an anatheistic wager: is it not cruel that my son died, and should I not let go of an omnipotent God that takes people like this? It is the existential question of a mother, disoriented in life, not-knowing where to go or how to believe. She leaps upon the anatheistic wager, knowing of death and suffering, bewildered by the meaning of existence, departing from the image of an omnipotent God, struggling with a God of love, because the death of her son was so unjust. Her writing exudes the atheistic "no" that may initiate the anatheist turn. And by clinging to the virtual procession, following the cross through the streets of Groningen city, she makes this turn: "Still, I walk along, virtually". Clearly not expecting to get one, she is hoping for an answer, for the return of God after his disappearance. In the existential darkness of her being, as the mother of a deceased child, the cross comes to her in a virtual but no less real way, and she throws herself in the arms of this radical strange cross. In her "holy insecurity", she keeps the possibility open for the divinity to return back to her in this moment. Her narrative is one big "no", her walking along in the procession is a

45 Source: Excel-file with motivations, acquired via Eo. Translation from Dutch to English language: $\mathrm{MK}$. 
"yes". Kearney writes that our response to the stranger is already a decision: a choice to commit. That is what this mother does, in a moment of truth, where she may not know the truth, but does the truth. Indeed, "Orthopraxis precedes orthodoxy. Trust precedes theory. Action precedes abstraction". ${ }^{46}$ In the moment of her surrender to this virtual procession, in the simple clicking of the button "I walk along" on the screen, the highest deity may kenotically become "the very least of these". The word that pitched a tent with the people empties itself out from a state of transcendence into the heart of her suffering, again becomes everyday flesh, transubstantiates to join this grieving mother. This example shows that the anatheistic space is about humans who, in dark times, have to let go: both of their children and of their images of God. God may be encountered right there.

\section{An Epiphanic Tweet: A Grandmother Joining the Twitter-Hashtag Procession}

On the same day, a female user on Twitter posted the text:

\#iwalkalong special \#thepassion I walk along for my grandson [name] who fights for his life in the IC of UMCG Groningen ${ }^{47}$

The following tweets, both replies to others and the original woman's response to those replies, disclosed that her grandson was very ill. The boy had been born after 25 weeks of pregnancy and had many health problems. ${ }^{48}$ By using the hashtag, and also by repeating the words, she virtually clasped the procession, joining other people in following the cross that was carried through the city. Although sending such a tweet is more volatile than virtually and physically following a cross through the streets of a city, the anatheistic wager is basically the same: in her experience of anxiety about her hospitalised grandchild fighting for his life, the online procession suddenly appears. In this moment, she clutches to the cross, dedicating her own processional act to her grandson, connecting the cross of the suffering Jesus to her own and her grandchild's suffering. She watches virtually behind the cross with her grandson, unintentionally (?) responding to Jesus' appeal to "watch with me for one hour"

\footnotetext{
$46 \quad$ Kearney, Anatheism 44.

47 Tweet sent on April 17, 2014, 5:17 p.m.. For privacy reasons the name of the Twitteraccount is not mentioned here. For verification of data it is available upon request.

48 The mother of the boy keeps a blog on the internet where she frequently posts medical updates about him. This section partly relies on information from that blog. For privacy reasons the web link is not mentioned here. For verification of data it is available upon request.
} 
(Matt 26:40), and therefore also watching with Christ. This opens the space for a sacramental inversion to take place, an exchange of perspectives: by welcoming the cross, the God who is welcomed may welcome the grandmother with her grandchild. ${ }^{49}$ In the past, the woman had posted several tweets about her grandson, as he had been hospitalised a number of times. This time, the processional tweet through, in and by which she links her grandson to the cross "somehow transubstantiates the empirical thisness [of her tweets, $\mathrm{MK}$ ] (...) into something sacred and eschatological", to use Kearney's words. ${ }^{50}$ An ordinary practice becomes a processional ritual that converts the ordinary into a sacred practice. It thus may become a sacramental vehicle that enables an encounter with the divine: the procession-tweet acquires an epiphanic character (i.e. it becomes an embodiment of the sacred), giving a future to past tweets.

\section{Conclusion}

In their reflections on the sacramentality of worship, the Dutch and South African theologians Barnard, Cilliers and Wepener rightly claim that God's presence cannot be manipulated. "God cannot be captured with or within our liturgical ritual acting. His 'real' presence - presentia realis - is an answer to human faith, but never in a causal sense". ${ }^{51}$ I by no means intend to claim that the ana-liturgical ritual causes God's presence. It is rather a matter of fides quaerens figuras: faith (and non-faith) searches for open spaces and forms in which to encounter the divine. I identify this as a theopoetic act: it makes clear "how the divine (theos) manifests itself as making (poiesis)".52 It is a second creation, called for(th) by the first creation: "creation again (ana): a double act where humanity and divinity collaborate in the coming of the Kingdom". ${ }^{33}$

In Dutch late-modern society, where classical liturgy and 'traditional' Christian beliefs are irrelevant in the eyes of an increasing amount of people, the media have re-invented the procession ritual. They have managed to turn a large amount of people with very diverse backgrounds into participants in the procession. Apparently, the conviction that Christian tradition (and, in its

\footnotetext{
49 An adequate elaboration of this sacramental inversion is found in Barnard, Cilliers and Wepener, Worship in the Network Culture, 323-354.

50 Kearney, Anatheism, 105.

$5^{1}$ Barnard, Cilliers and Wepener, Worship in the Network Culture, 330.

52 Kearney, "God Making. Theopoetics and Anatheism", in The Art of Anatheism, eds. Kearney and Clemente, $3-28$, here 3 .

53 Kearney, “God Making”, 3.
} 
slipstream, God) is irrelevant, makes 'religious' practices no longer simply 'not done'. In a post-secular context, religious practices are no longer apologetic, but have transformed into interpretative and contributory practices: the resources of traditions are made available to meaning-making and to the quest for the good life and for the sake of human flourishing. ${ }^{54}$ The opposition between the religious and the secular has been weakened, maybe even surpassed, and there I find a breeding ground for what Kearney calls anatheism. The Passion is announced and organised, people see a strange cross approaching and the procession obtains new, diverse and layered meanings. Part of this society welcomes the cross, either in the physical procession or in virtual form on the second screen or on Twitter. By engaging in this procession ritual, participants very often turn out to actively connect themes related to the procession (e.g. suffering, pain, cross, sacrifice, death) to events they (have) experience(d) in their personal lives, as in the examples that I discussed. ${ }^{55}$ In doing so, they may have encountered the divine in a new way.

The three examples of openness towards the cross that I discussed above have showed how - in the moment and action of connecting their ordinary life, sorrow, grief, pain, health, loved ones, and all darkness to the cross - a space is created in which God, who has never really completely disappeared, can return to people and meet them. A space in which they are (again) presented with the freedom to choose, to imagine different possibilities, and encounter anew. This leads to the conclusion that Dutch society is not simply a society beyond God, and that to (at least part of) its members the re-invention of liturgical ritual is of the utmost importance.

54 See Benjamins, "The Postsecular and Systematic Theology", 116.

55 This claim is, among other things, supported by people's motivations for joining the virtual procession, as derived from the motivations virtual procession-excel sheet (2014 and 2015). Documents obtained via broadcasting company EO. 